\title{
Cumulative causation in the formation of a technological innovation system: The case of biofuels in the Netherlands
}

\author{
Roald A.A. Suurs *, Marko P. Hekkert \\ Innovation Studies Group, Copernicus Institute for Sustainable Development and Innovation, Utrecht University, Heidelberglaan 2, 3584 CS Utrecht, The Netherlands
}

\section{A R T I C L E I N F O}

\section{Article history:}

Received 18 February 2008

Received in revised form 4 March 2009

Accepted 4 March 2009

\section{Keywords:}

Technological innovation system

Emerging sustainable technology

Event history analysis

Biofuels

\begin{abstract}
A B S T R A C T
Despite its worldwide success, the innovation systems approach is often criticised for being theoretically underdeveloped. This paper aims to contribute to the conceptual and methodological basis of the (technological) innovation systems approach. We propose an alteration that improves the analysis of dynamics, especially with respect to emerging innovation systems. We do this by expanding on the technological innovation systems and system functions literature, and by employing the method of 'event history analysis'. By mapping events, the interactions between system functions and their development over time can be analysed. Based on this it becomes possible to identify forms of positive feedback, i.e. cumulative causation. As an illustration of the approach, we assess the biofuels innovation system in The Netherlands as it evolved from 1990 to 2007.
\end{abstract}

(c) 2009 Elsevier Inc. All rights reserved.

\section{Introduction}

The literature on innovation systems stresses the importance of path dependency, positive feedback and cumulative causation for understanding technological change and long-term economic growth [1-4]. However, our insight into what more generally could be called system dynamics is still limited $[5,6]$. The majority of innovation system studies conducted so far start from the aggregated perspective of a national or sectoral economy. The scope and complexity of such systems make a thorough analysis of dynamics difficult. As a result of this, most empirical studies aim at making static comparisons. Our understanding of innovation system dynamics is especially lacking for systems that are only just emerging [6,7]. This is a crucial problem since it is these innovation systems that can still be shaped and influenced; cf. Collingridge [8].

The conscious shaping of an innovation system becomes especially relevant when one considers that technological change plays a crucial role in the transition to a sustainable energy system. The fluidity of emerging innovation systems makes the task of supporting sustainable energy technologies extremely challenging. This is illustrated by their exceptionally low market shares, despite efforts by many European governments to support their development [9]. Currently, renewables are locked-out of the energy system [10]. This not only implies the absence of a well-functioning market for renewables but also an immature supply system and poor-or unfitsupporting infrastructures, in terms of technology, policy, knowledge bases, finance, user communities etc.

Even if trust is placed in a particular emerging technology, it is still unclear how it should be supported [11]. Therefore, the aim of this study is to contribute to insights into the innovation system dynamics that induce or block the successful development and diffusion of emerging sustainable energy technologies. We do this by, theoretically and methodologically, expanding on the Technological Innovation Systems (TIS) approach [3]. ${ }^{1}$ The TIS is a social network, constituted by actors and institutions, which is constructed around a specific technology. ${ }^{2}$ Recent TIS literature stresses that emerging technologies need to pass through a

\footnotetext{
* Corresponding author: Tel.: +3130 2532782.

E-mail address: r.suurs@geo.uu.nl (R.A.A. Suurs).

1 Carlsson and Stankiewicz actually use the term 'technological system' instead of 'technological innovation system', but this term usually refers to the notion of a 'large technological system' (LTS) introduced by Hughes [3,12]. To avoid confusion we choose to stick to the term that now has largely proliferated within the literature.

${ }^{2}$ A more precise definition will be given in the next section.
} 
formative stage before they can be subjected to a market environment [6]. During this formative stage, market diffusion is typically absent or insignificant, but actors are drawn in and technologies and institutions are designed and adjusted. In short, structures are shaped that, positively or negatively, influence the emerging technology.

In many studies on innovation systems, these system structures are regarded as static, rendering them unfit to deal with technology dynamics [6]. Alternatively, following Rickne, Liu and White, Edquist, Bergek and Jacobsson, the build-up, or breakdown, of innovation system structures can be conceptualised in terms of key activities, or system functions [6,13-16]. Examples of such system functions are Entrepreneurial Activities, Knowledge Development, and Resource Mobilisation [5]. It is expected that by mapping the fulfilment of system functions over time a better understanding of the formative stage will be developed. The core of our analysis is to point out occurrences of positive feedback, or cumulative causation. Recent TIS studies suggest that cumulative causation can be captured by pointing out interactions between system functions [5,6,13].

This direction of research is supported by Edquist [14]. However, he also states, in his overview of innovation systems literature, that there remains a conceptual diffuseness to most IS studies. One reason is that empirics are often only superficially related to theory, and vice versa. Edquist suggests that one way to increase theoretical depth is to provide a clear description of system functions (activities) [14]. Another important recommendation is to integrate conceptual work more with in-depth empirical studies. We need insights into the particular dynamics of specific, historically-embedded technological trajectories.

In this study we take up this recommendation by analysing an empirical case and by introducing a new method for operationalising cumulative causation in innovation systems: an event history analysis [17]. This approach takes 'events' as elementary units of analysis. This means that the unfolding of system functions over time is mapped in terms of events and sequences of events. Based on the sequences, we identify forms of cumulative causation, and indicate how these influence the historical formation of a TIS.

Our empirical focus is on the developments around biofuels in the Dutch automotive sector (1990-2007). The automotive sector is an interesting domain since, in order to reduce oil dependency and to meet (post-)Kyoto climate targets, the automotive sector is a crucial, and yet until recently highly neglected, target for innovation policy [18]. This brings us to the following research question:

\section{How did innovation system dynamics influence the formation of a Dutch biofuels innovation system from 1990 to $2007 ?$}

Section 2 describes our theoretical approach. Section 3 explains the method of event history analysis. Section 4 provides the application of theory and method in the case study on Dutch biofuels. Section 5 provides a reflection on the results. Finally, Section 6 concludes by discussing the contribution of this paper to innovation systems research. Throughout the paper, policy implications are addressed.

\section{Theory}

From the 1980s onwards, innovation system studies have pointed out the influence of the social system on innovative performance. Different approaches exist-for an extended review, see Carlsson et al. [2], Lundvall et al. [19] and Freeman [20]. All these approaches point to the structure of the innovation system as the explanatory basis. This idea has been well developed by Lundvall [4,21], who stresses the importance of a broad selection of societal sub-systems, from R\&D laboratories and production facilities to financial and educational systems, in their contribution to the national innovation process.

Such a conception is highly relevant to understand macro-economic differences between modern states. However, as Carlsson and Stankiewicz [3] argue, this national innovation systems approach fails to address the question of whether specific technological innovations are successful or not. In this case the characteristics of structures that constitute a technological field are more important determinants. These may persist just as well across as within national borders. A second point of criticism, which holds for innovation systems studies more generally, is the static perspective of the approach. Mapping the contours of innovation systems and analysing the (lack of) interaction between components does not explain how a system comes about.

A dynamic framework is required, especially when one is interested in emerging technologies, such as sustainability innovations. Many studies have provided conceptual and empirical evidence that supports the usefulness of the TIS approach for this purpose $[5,13,22-24]$. We follow this strand of literature in defining the biofuels TIS as those structural elements (and their mutual relations) that directly support (or reject) the development and (eventually) the diffusion of biofuels in the Netherlands. ${ }^{3}$ These consist of actors, institutions, and the networks through which these are connected [2]. The structure the TIS also incorporates technological features [25]. ${ }^{4}$ The configuration of structural factors is expected to influence the rate and direction of technology diffusion.

A TIS approach may focus on structures and their effects but it may also focus on the processes underlying the formation of the system. Recently, scholars have made progress by suggesting how a TIS assessment can provide a dynamic perspective by keeping track of system functions as they unfold through time $[5,6,13,14,25]$. System functions are considered to be the processes that are necessary for TIS build-up to occur.

System functions are system-level variables. They are to be understood as types of activities, or sets of activities, that influence the build-up of an innovation system. Each system function may be 'fulfilled' in a variety of ways. With this conceptualisation it is

\footnotetext{
3 This is based on the following definition by Carlsson and Stankiewicz: 'A [TIS] may be defined as a network of agents interacting in the economic/industrial area under a particular institutional infrastructure (...) and involved in the generation, diffusion, and utilisation of technology.' [3], (p. 93).

4 Traditionally, technology, as an explanatory factor, is not very central in the literature on innovation systems. However not considering technological features as part of the TIS structure implies that a crucial feedback mechanism-between technological change and institutional change-is neglected. Therefore we will consider technological features as part of the TIS structure.
} 
also possible to consider activities that negatively contribute to a system function. Obviously, these negative contributions imply a (partial) breakdown of the TIS.

The premise is that a TIS should positively realise multiple system functions, each of which covers a particular aspect of technology development. Based on a review of innovation systems literature, a shortlist of seven system functions has been formulated [5]; see Table 1 for definitions.

Various 'lists' of system functions have been constructed [13-16,26-28]. Authors like Bergek et al., Hekkert et al. and Suurs give useful overviews $[5,29,30]$. The lists show much overlap and differences reside mostly in the particular way of clustering activities. However, we agree with Edquist that our knowledge is still provisional and needs to be adjusted as our insight grows. The list needs to be confirmed (or falsified) by empirical evidence [14]. For a large part such empirical validation has been provided, for instance, in studies by Negro, Alkemade and colleagues [23,24,31]. These studies support our assumption that the set of system functions as given above corresponds well to the empirical data relevant in the field of sustainability innovations.

The seven system functions are considered a suitable set of criteria for the assessment of a TIS in the formative stage. We expect that as actors, institutions, technologies and networks are successfully arranged to induce the fulfilment of system functions, the chances of technology diffusion will increase. To some extent, system functions need to be realised simultaneously, since they can complement each other. A TIS may very well break down due to the absence of a single system function. For example, Kamp [32] shows that the Dutch wind energy innovation system was well developed in the 1980s but collapsed as the result of an important deficiency, namely the absence of Knowledge Diffusion between the emerging turbine industry and potential users, the latter being energy companies in particular.

This means that system functions are expected to reinforce each other over time. Indeed, a positive interaction between system functions is considered necessary for TIS build-up to occur. According to Jacobsson and Bergek [33], the fulfilment of system functions may result in a virtuous cycle. For example, the successful realisation of a research project, contributing to Knowledge Development [F2], may result in high expectations, contributing to Guidance of the Search [F4] among policy makers, which may, subsequently, trigger the start-up of a subsidy programme, contributing to Resource Mobilisation [F6], which induces even more research activities that contribute to Knowledge Development [F2], Guidance of the Search [F4], etc. Thus, interaction between system functions results in cumulative causation.

Multiple forms of cumulative causation may exist. In the ideal situation, the sequence of activities will form a virtuous cycle and trigger a take-off. Conversely, a sequence may also result in conflicts, a complete standstill, or even a vicious cycle. In short, multiple sequences are conceivable that result in a positive, or negative, development process. In this respect our approach reflects the opposition of the innovation systems approach to the linear model that states that technology development is characterised by a fixed sequence of activities: R\&D, prototype testing, niche-market development, up-scaling; cf. Lundvall [21]. The identification of various forms of cumulative causation, or motors of innovation as they can be called [34,35], will be at the core of our analysis.

Motors of innovation cannot be regarded as independent of the structures of a TIS. On the contrary, motors of innovation emerge from a configuration of structural factors and in turn rearrange that configuration. There exists a mutual relation between the structural configuration of a TIS and the system functions which are realised in it. For the purpose of this paper, the focus will be on the dynamic aspect, i.e. the system functions. Nevertheless, the most important actors, institutions and technologies that actually make up the TIS will be revealed in the analysis. In fact, as will become clear in the next section, system functions are always directly related to such structural factors.

Note that the dynamics that unfold through the emergence of cumulative causation are primarily the result of factors (or events) internal to the TIS. However, they will be influenced by external factors as well, such as technical possibilities, historical shocks, and international trends. These will be mentioned in the analysis as background movements.

\section{Method}

The analysis of a TIS in the formative stage requires a methodology that captures the microdynamics that contribute to its realisation. Traditional methods fall short here. For example, bibliometric methodologies, as applied to publications or patents, are

Table 1

Functions of technological innovation systems.

F1. Entrepreneurial Activities At the core of any innovation system are the entrepreneurs. These risk takers perform the innovative commercial experiments, seeing and exploiting business opportunities.

$\begin{array}{ll}\text { F2. Knowledge Development } & \text { Technology research and development (R\&D) are prerequisites for innovation. R\&D activities are often performed by } \\ \text { researchers, but contributions from other actors are also possible. }\end{array}$

$\begin{array}{ll}\text { F2. Knowledge Development } & \text { Technology research and development (R\&D) are prerequisites for innovation. R\&D activities are often performed by } \\ & \text { researchers, but contributions from other actors are also possible. }\end{array}$

F3. Knowledge Diffusion information exchange.

F4. Guidance of the Search This system function represents the selection process that is necessary to facilitate a convergence in development, involving for example, policy targets, outcomes of technical or economic studies and expectations about technological options.

F5. Market Formation New technologies often cannot outperform established ones. In order to stimulate innovation it is necessary to facilitate the creation of (niche) markets, where new technologies have a possibility to grow.

F6. Resource Mobilisation Financial, material and human factors are necessary inputs for all innovation system developments, e.g., investments by venture capitalists or governmental support programmes.

F7. Support from Advocacy Coalitions The emergence of a new technology often leads to resistance from established actors. In order for an innovation system to develop, actors need to raise a political lobby that counteracts this inertia, and supports the new technology. 
limited to the analysis of Knowledge Development, while social network analysis is limited in that it detects only network formation, i.e., Knowledge Diffusion or Support from Advocacy Coalitions. Similarly, firm data are well suited to analyse Entrepreneurial Activities, but are less suitable to construct indicators for other system functions. A more flexible, yet systematic, methodology to analyse the realisation of system functions is the event history analysis, as developed in the context of organisation studies; see Poole et al. [17]. The event history analysis employs a particular worldview, based on a so-called process approach which can be summarised according to the following assumptions:

- The world is made of entities that perpetually participate in events. These entities may change over time. With respect to the TIS, this means that structural factors are to be considered as subjects of change.

- The world can be understood as a development process in which these events form one or more sequences. To understand a development process is to understand the logic of a sequence of events.

- The logic of event sequences is the logic of a plot in a narrative. Events that are part of a plot are not (only) related to each other by an efficient causality (the simple logic of mechanics) but (also) by final and formal causality. Final causality relates to the goal directedness of agents, whereas formal causality refers to the intangible forces that shape actions, like routines, regulations, institutions and technologies.

The main implication for the analysis in this paper is that system functions do not represent variables in the traditional sense. Instead system functions may be understood as (interpretative) categories of events. In line with this, motors of innovation are to be understood as event sequences that correspond to a meaningful 'plot'. See Suurs [30] for an extended overview of this idea.

The event history analysis offers the possibility of operationalising and measuring system functions by relating them to events. Within the context of a TIS analysis, an event can be defined as an instance of change with respect to actors, institutions and/or technology which is the work of one or more actors and which carries some public importance with respect to the TIS under investigation. Examples of such events are studies carried out, conferences organised, plants constructed, policy measures issued etc. Note that events are directly associated with structures. Hence, system functions are always about (changing) structures.

The basis of the event history analysis is the construction of a narrative. The following procedure explains how to do this and how to distil meaningful event sequences.

\subsection{Collect data from literature}

A variety of literature was collected, including professional journals, newspapers, periodicals, reports, websites. See Table 2 for an overview of all sources used. In total about 1100 events were retrieved to form the basis of our analysis. An important aid was the Lexis Nexis database in which a large number of source are digitally available. The following keywords were used (translated from Dutch); bio(-)fuel, bio(-)ethanol, bio(-)diesel, dme (dimethylether), fischer-tropsch, htu (hydrothermal upgrading), pure plant oil, ppo (pure plant oil).

\subsection{Construct a database}

A database was constructed containing events in chronological order. This was done by reading through the literature and separating, throughout each text, the events reported. The identification of events was an inductive exercise for which the conceptual framework of system functions was used as a heuristic, in the sense that with the definitions of system functions in mind it was possible to interpret particular reports as events. In this respect the events should be considered constructs of the researcher. They make up an intermediate level of representation that lies between the concrete literature reports and the abstract concepts.

\subsection{Mapping events to system functions}

The database provided an overview of the content of events and the time of their occurrence. Based on this overview, the events were clustered into types that corresponded to the system functions. The outcome, an event typology, is presented in Table 3. Note that each event type is mapped on a particular system function. This way events serve as indicators of system functions. ${ }^{5}$

Events can contribute to system functions either positively or negatively. Therefore, the events in the database were categorised as either positive or negative. For example, events that were categorised as Guidance of the Search were rated positive/negative when they expressed a positive/negative opinion regarding the technology under investigation. Likewise, within the category of Support from Advocacy Coalitions, there were positive lobbies and negative lobbies. ${ }^{6}$

\footnotetext{
${ }^{5}$ It is conceivable that an event contributes to multiple system functions. For example, setting up an industry association may be considered to contribute to Knowledge Diffusion, Guidance of the Search and Support from Advocacy Coalitions. In this study we try to avoid this ambiguity by explicitly distinguishing and mentioning the various actions related to this structure. For example, we classified the creation of the branch organisation itself as contributing to Knowledge Diffusion, the promises it makes to Guidance of the Search and the lobbying it undertakes to Support from Advocacy Coalitions.

${ }_{6}^{6}$ Note that a negative contribution to a system function is not necessarily a bad thing in the long run. For example, negative expectations may be the result of important technological disadvantages that turn out to be impossible to overcome. This way, a negative Guidance of the Search signifies the exclusion of a badly performing technology. Nevertheless, the immediate consequence is a (partial) breakdown of the TIS.
} 
Table 2

Literature sources.

\begin{tabular}{|c|c|c|c|}
\hline Professional journals & National news & & \\
\hline Agrarisch Dagblad & Algemeen Dagblad & Dagblad van het Noorden & Rotterdams Dagblad \\
\hline Boerderij & ANP & Dagblad voor Zuidwest-Nederland & Utrechts Nieuwsblad \\
\hline Duurzame Energie & De Telegraaf & De Dordtenaar & Veluws Dagblad \\
\hline Energie- en Milieuspectrum & De Volkskrant & De Gelderlander & Zwolse Courant \\
\hline GAVE Newsletter & Elsevier & Deventer Dagblad & \\
\hline Logistiek Krant & NRC Handelsblad & Eindhovens Dagblad & Financial news \\
\hline \multirow[t]{2}{*}{ Stromen } & Trouw & Gelders Dagblad & AFX - NL \\
\hline & & Goudsche Courant & $\mathrm{BIZZ}$ \\
\hline Web sites & Regional news & Haagsche Courant & FEM Business \\
\hline Website and Publications ECN & BN/DeStem & Het Parool & Het Financieele Dagblad \\
\hline Website NEO & Brabants Dagblad & Leeuwarder Courant & \\
\hline Websites Senter, Novem, SenterNovem & Dagblad Flevoland & Provinciale Zeeuwse Courant & \\
\hline Website VROM & Dagblad Tubantia/Twentsche Courant & Rijn en Gouwe & \\
\hline
\end{tabular}

It is important to remark that the system functions guided the interpretation of the literature but did not force it. When important events could not be allocated to either one of the seven functions, this would have been an indication of an incomplete set of system functions. Also, if for a specific system function only a small number of events would have been found without a clear indication of bad system performance, this system function would have been considered as irrelevant (unless explanations could be mobilised to account for it). In this case, all event types could be mapped on the current set of system functions, which is a (tentative) validation of the seven system functions used here. The allocation scheme resulting from our literature search is given in Table 3.

\subsection{Patterns of events}

The next step was to analyse the event data. Based on the ideas of Abell [36] and Poole et al. [17], event data were subjected to two types of analysis. Both are based on the recognition of patterns in event data: trend patterns and interaction patterns. Both techniques are means to develop a plot, and thereby to construct a meaningful narrative that captures the development of a TIS.

Table 3

Measurement scheme for mapping empirical events to system functions.

\begin{tabular}{|c|c|c|c|c|}
\hline System function & Event type & Description & $N$ & Sign \\
\hline F1. Entrepreneurial & Portfolio expansion & A (vested) actor explores activities without any previous experience. & 11 & + \\
\hline \multirow[t]{2}{*}{ Activities } & Project entry/Start & Technology is explored within a societal context and/or with a commercial goal. & 95 & + \\
\hline & Project exit/Failure & Exploration activities are cancelled. & 19 & - \\
\hline F2. Knowledge & Opinion & Actors' critical notes on institutions and/or past developments. & $\mathrm{N} / \mathrm{A}$ & $\mathrm{N} / \mathrm{A}$ \\
\hline \multirow[t]{2}{*}{ Development } & Learning by exploring & Assessment research with no direct commercial orientation. & 121 & + \\
\hline & Learning by doing & Practical research with no direct commercial orientation. & 45 & + \\
\hline \multirow[t]{2}{*}{ F3. Knowledge Diffusion } & Networks, Coalitions & Co-operation between actors. & $\mathrm{N} / \mathrm{A}$ & $\mathrm{N} / \mathrm{A}$ \\
\hline & Meetings & Workshops, conferences, etc. & 61 & + \\
\hline \multirow[t]{10}{*}{ F4. Guidance of the Search } & $\begin{array}{l}\text { Classification, Standard } \\
\text { setting }\end{array}$ & - & 3 & + \\
\hline & Doubt, Uncertainty & Expression of the technology's uncertain circumstances. & $\mathrm{N} / \mathrm{A}$ & $\mathrm{N} / \mathrm{A}$ \\
\hline & Expectations positive & Expression of the technology's future expectations. & 224 & + \\
\hline & Expectations negative & Negative expressions of the technology's future expectations & 46 & - \\
\hline & Award & - & 5 & + \\
\hline & Outcome study positive & Positive results of research and trials, often mentioned when reports are published. & 81 & + \\
\hline & Outcome study negative & Negative results of research and trials. & 32 & - \\
\hline & Promises or targets positive & $\begin{array}{l}\text { Promises by actors with the power to change institutions, complementing the } \\
\text { technology. }\end{array}$ & 171 & + \\
\hline & Promises or targets negative & Promises by actors with the power to change institutions, hampering the technology. & 22 & - \\
\hline & Technological guide, Manual & Aid to support entrepreneurs. & 10 & + \\
\hline \multirow[t]{3}{*}{ F5. Market Formation } & Tax exemption starts & - & $\mathrm{N} / \mathrm{A}$ & $\mathrm{N} / \mathrm{A}$ \\
\hline & Tax exemption stops & - & $\mathrm{N} / \mathrm{A}$ & $\mathrm{N} / \mathrm{A}$ \\
\hline & Niche markets & $\begin{array}{l}\text { Protected spaces where practical experiments can be conducted in a market } \\
\text { environment. }\end{array}$ & $\mathrm{N} / \mathrm{A}$ & $\mathrm{N} / \mathrm{A}$ \\
\hline \multirow[t]{3}{*}{ F6. Resource Mobilisation } & Feedstock & Content related to availability of biomass resources. & $\mathrm{N} / \mathrm{A}$ & $\mathrm{N} / \mathrm{A}$ \\
\hline & Investments, Subsidies & Including dedicated subsidy programmes. & 27 & + \\
\hline & Resource refusal & Rejection of financial support and cutbacks. & 1 & - \\
\hline F7. Support from Advocacy & Dissent & Conflicting interests around the technology. & $\mathrm{N} / \mathrm{A}$ & $\mathrm{N} / \mathrm{A}$ \\
\hline \multirow[t]{2}{*}{ Coalitions } & Lobby or advice pro & Pressure on actors in power to change institutions, complementing the technology. & 138 & + \\
\hline & Lobby or advice contra & Pressure on actors in power to change institutions, hampering the technology. & 20 & - \\
\hline
\end{tabular}

Of the event types used for quantitative analysis, the number of events available is given, as well as whether its effect is positive or negative with respect to its contribution to the BFTIS (sign). 


\subsubsection{Trend patterns}

The first technique aims to derive trends from aggregated data over a period of time. Ideally, this is done quantitatively by plotting the aggregated number of events for each year per system function. The slope of the graph represents the increase or decrease in the activities per system function. This representation is useful as it gives insight into major turning points of the TIS development such as, for instance, a sudden decline in the intensity of the Guidance of the Search function. If the available data allows it, more detailed insight can be obtained into the way system functions are specifically fulfilled. For example, the analysis could show a shift in the share of activities conducted by particular actors (public or private). Alternatively, there may be shifts in the share of different technological varieties being developed (as, in our case, with respect to a first-generation and a second-generation of biofuels).

\subsubsection{Interaction patterns}

The second technique aims to track causal chains of events based on the sequence in which they occur. If trend patterns represent outcomes of TIS development, then interaction patterns offer a possible explanation for these outcomes. To understand this, it is important to realise that events can be connected through 'leads-to' relations, to form a sequence; cf. Abell [36]. Many events refer to other events; these references can be tracked by checking the content of the events in the database. For example, a promise to support the construction of a biofuels plant may be followed by the construction of that plant. Also, a positive lobby may result in the award of subsidies or the adjustment of institutions.

The overview of event references enables us to construct a narrative in which event sequences serve to construct storylines. By interpreting events as indicators of system functions, according to Table 3, it becomes possible to identify the role that particular system functions play within event sequences. If particular system functions recur in an ordered sequence, this implies a cyclic mechanism: a motor of innovation. The event sequence indicates a virtuous cycle if it forms a repetitive loop of system functions reinforcing each other. The example of the virtuous cycle presented in Section 2 was already formulated in terms of events: the successful realisation of a research project (Knowledge Development) results in high expectations (Guidance of the Search) among policy makers, which subsequently triggers the start-up of a subsidy programme (Resource Mobilisation) which induces even more research activities (Knowledge Development). A vicious cycle would involve a cascade of negative events.

Note that event sequences may diverge, as one event may lead to multiple other events, or converge, as multiple events may be necessary before they can lead to one other event. I will attempt to reduce this complexity by summarising such leads-to relations on the level of system functions. For example, by stating that an important policy measure (Guidance of the Search) results in an increase of firm entry (Entrepreneurial Activities).

Insights from both analyses mutually strengthen each other. The trend patterns can be used to distinguish and characterise particular 'episodes' in the narrative. The interaction patterns unfolding within an episode may explain the occurrence of the trend patterns.

\subsection{Triangulation}

The construction of the event sequences and the narrative is done as 'objectively' as possible based on empirical sources. Still, the interpretation of the researcher is a crucial factor. To minimise personal bias, the narrative is verified, i.e., triangulated, and if necessary reconstructed, by including feedback from interviews with experts. ${ }^{7}$ In this case, the expert feedback led only to minor adjustments of the storyline.

In the next section, we reconstruct the development of the BioFuels TIS (BFTIS) and refer to the various system functions as F1, F2, F3 etc., following Table 1. The narrative is chronologically ordered and divided into six episodes. Motors will be identified for each episode, if present. The background movements of the BFTIS are covered as an introduction to each separate episode.

\section{The event history of the BFTIS}

Before starting the narrative, it is important to introduce a remarkable (technological) feature of the BFTIS, namely the existence of two distinct technology groups: first-generation (1G) and second-generation (2G) biofuels. Both technology groups connect to different knowledge bases and separate sectoral backgrounds. The 1G fuels are based on conventional technologies, mainly adopted by farmers' organisations. Agricultural crops are used, such as rapeseed or sugar beet, to produce biodiesel or bioethanol. The $2 \mathrm{G}$ biofuels originate from science-based technologies (chemical and biotechnological). These technologies involve the conversion of woody biomass, consisting of waste wood or cultivated energy crops, into 'biocrude', 'Fischer-Tropsch biodiesel' or 'cellulosic bioethanol' (all synthetic substances).

Both $1 \mathrm{G}$ and $2 \mathrm{G}$ biofuels are currently in a pre-commercial stage of development. For $2 \mathrm{G}$ biofuels the distance-to-market is much larger than for $1 \mathrm{G}$ biofuels. It is expected that-in the long term-2G biofuels offer the possibility for larger reductions in $\mathrm{CO}_{2}$ emissions at lower costs than $1 \mathrm{G}$ fuels. ${ }^{8}$ Another advantage of $2 \mathrm{G}$ biofuel technologies is that they can draw upon a wider variety of

\footnotetext{
${ }^{7}$ Seven interviews have been conducted with biofuels experts: entrepreneurs, senior policy makers and policy researchers. Also numerous informal conversations with researchers and policy experts have been used to check key insights.

${ }^{8}$ For a condensed technological overview of the different types of biofuels, see Schubert [37].
} 
biomass resources, including waste materials. On the other hand, the $1 \mathrm{G}$ biofuels seem to offer a better perspective in terms of costs and implementation in the present and in the near future. As will be shown, the dynamics of the Dutch BFTIS largely revolve around a clash of these two technology groups.

With respect to utilisation in vehicles, biofuels may be used in their pure form but then significant vehicle changes are necessary. For blends, only minor changes are necessary. The exception to this is Fischer-Tropsch biodiesel, which can be used in regular diesel engines.

\subsection{Emerging biofuel technologies (1990-1994)}

During the early 1990s, there is no political urgency for a sustainable energy system. Oil prices are low and the climate issue is barely mentioned in (international) political arenas. The biofuels issue arises in Europe as an effect of a background movement: the decline of the agricultural sector. The European trade protectionism of the past decades has resulted in massive production surpluses and an unacceptable budgetary burden [38]. In countries such as France and Germany, where (bulk) agriculture is relatively important, biofuels are first presented as a way out of this impasse. With the production of non-food crops, the sector could be aligned with a new market with new opportunities. In 1992, within the context of this 'agrification' idea, Europe proposes to financially support biofuels [39] by proposing a scheme for generic tax exemptions. Furthermore, farmers are offered a premium for the cultivation of non-food crops. Environmental benefits are mentioned as the prime reason for these subsidies $[40,41]$.

In the Netherlands, this background movement is picked up by a group of entrepreneurs who start adopting biofuels [F1]. In the rural province of Groningen, a public transport company starts a trial [F2] with bioethanol in buses. A number of actors is involved, among them the alcohol producer Nedalco [42]. Another trial [F2] is started in the city of Rotterdam, where buses are fuelled with biodiesel. Funding is provided by the companies themselves and through European subsidies [F6]. Figs. 1 and 2 illustrate that these and other entrepreneurial experiments and trials [F1, F2], are the first signs of a Dutch BFTIS taking shape. The trials [F2] turn out to be technically successful [F4] despite the fact that the engines of the buses in Groningen incidentally catch fire [43]. A less positive outcome of the experiments is their low economic feasibility: under the present circumstances, biofuels cannot compete with fossil fuels [F4].

At this time biofuels fall under the same tax legislation as fossil fuels. Measures of national support are absent [F4, F5]. This relates to the emergence of a controversy around the use of biofuels. Illustrative of this is that, in 1992, the Dutch government agency for energy and environment (Novem) states that implementation of biofuels is too expensive compared with co-firing biomass in power plants [F4] [44,45]. Various assessment studies [F2] now set the tone for a 'debate' [F4] that will go on until today. Regional actors emphasise the strategic and environmental value of biofuels, whereas scientists and environmentalists stress their meagre performance. The Dutch government initially remains silent due to its internal division on the biofuels issue [F4]. In spring 1993, the Ministry of Agriculture takes a stance against public support [F4] [46], whereas the advisory council on social-economic issues (SER) advises it to support the experiments [F7] [47, 48]. Only a year later, in 1994, the Ministry of Agriculture decides to announce fiscal support of biofuels [F4], whereas the Ministry of the Environment expresses doubt [F4] [49].

\section{Cumulative causation}

In this first episode, the system functions are beginning to take shape; they are mainly driven by external factors. There is no indication of a cumulative causation internal to the BFTIS. An important trend pattern-one which will be very influential-is a slumbering turmoil with respect to the Guidance of the Search: see the negative peaks in Fig. 3 offsetting the weaker positive ones.

\subsection{The shaping of the BFTIS (1995-1997)}

From 1995 onwards, a background movement is the gradual shift within the international energy domain; the climate issue is becoming a matter of political interest and the concept of biomass is becoming important in the energy sector [50,51].

In the Netherlands, a first series of projects is initiated which contributes to a sequence of further activities. It starts in 1995 in the rural province of Friesland, where two boating companies initiate adoption experiments with biodiesel [F1] [52]. An important reason is the increasing regulatory pressure with respect to the surface water quality [F4]. Biodiesel is biodegradable and poses only a limited threat to the water quality. The companies demand a national fuel tax exemption for the project [F7]; the provincial government and the district board of agriculture support the idea by forming an advocacy coalition towards the national government [F7]. They are successful and a first tax exemption is provided, for two years [F6] [52]. As the province decides to adopt biodiesel for its fleet of service boats, a virtuous cycle emerges. The adoption experiment improves existing knowledge [F2] and, most importantly, it serves as an example to others in the field [F4]. Several other boating projects start [F1] (see Fig. 1) and once again tax exemptions are demanded [F7], and issued [F6]. Subsequently, the 1G technologies gain even more attention [F4], especially due to the positive outcome of the trials [F2].

A crucial barrier to these developments is that, meanwhile, various impact assessments [F2] yield contradictory or negative results for $1 \mathrm{G}$ fuels [F4]. Fig. 3 shows the negative climax of this movement in 1996. The national government does not take a clear stance in the debate, as tax exemptions are issued on project-specific grounds [F6] instead of on the basis of a policy strategy. There is at this point in time no structural form of support [F4]. An issue that keeps coming up in this respect is the budgetary gap that would have to be filled if a generic fuel tax exemption was to be issued [F5] [53]. 


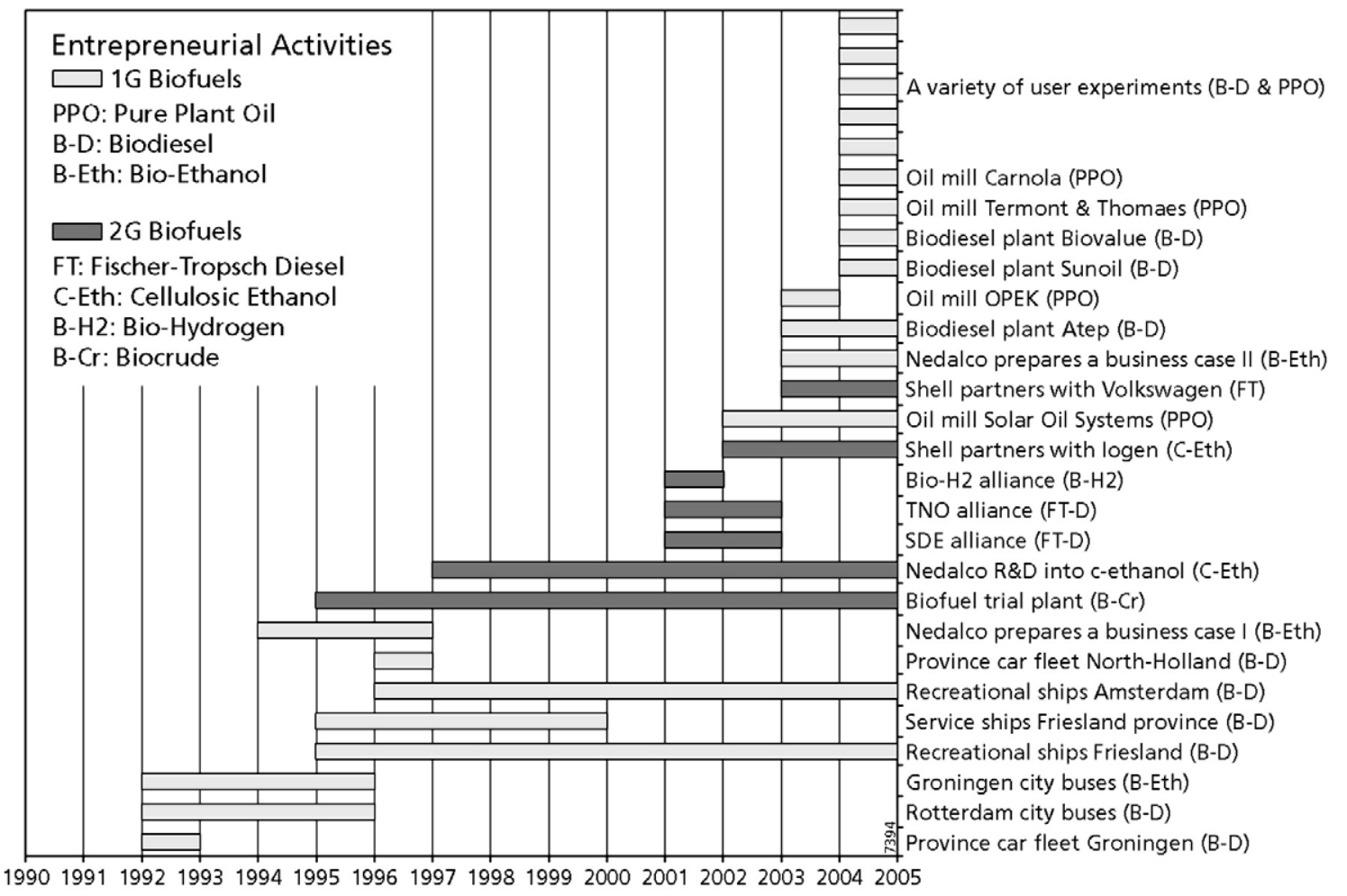

Fig. 1. Key events related to Entrepreneurial Activities [F1].

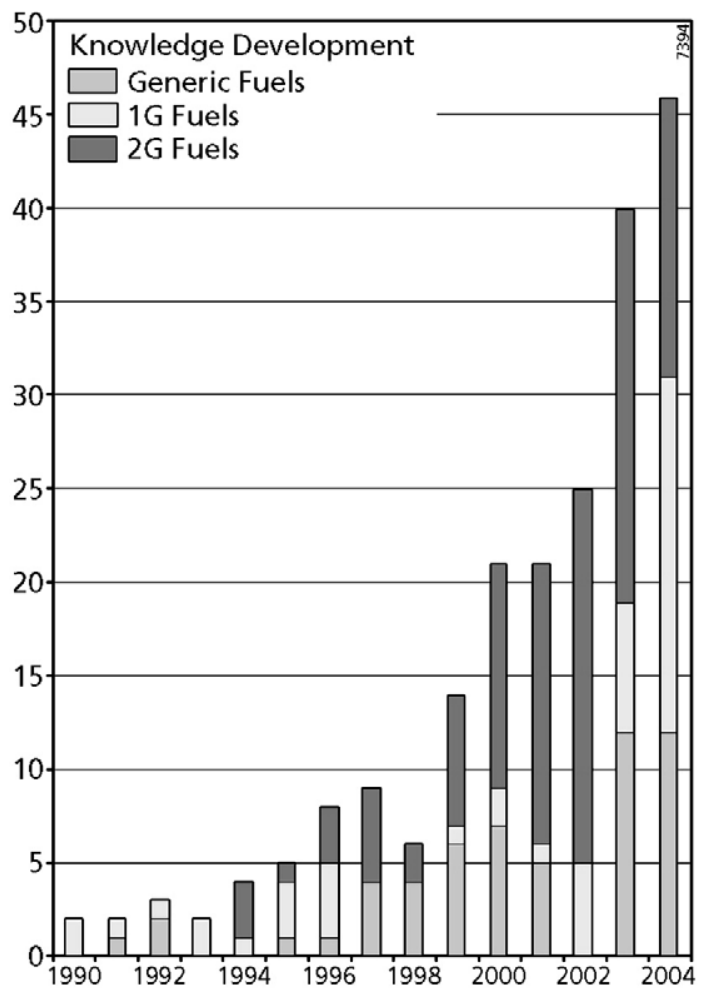

Fig. 2. Knowledge Development [F2] [aggregated events/year]. 


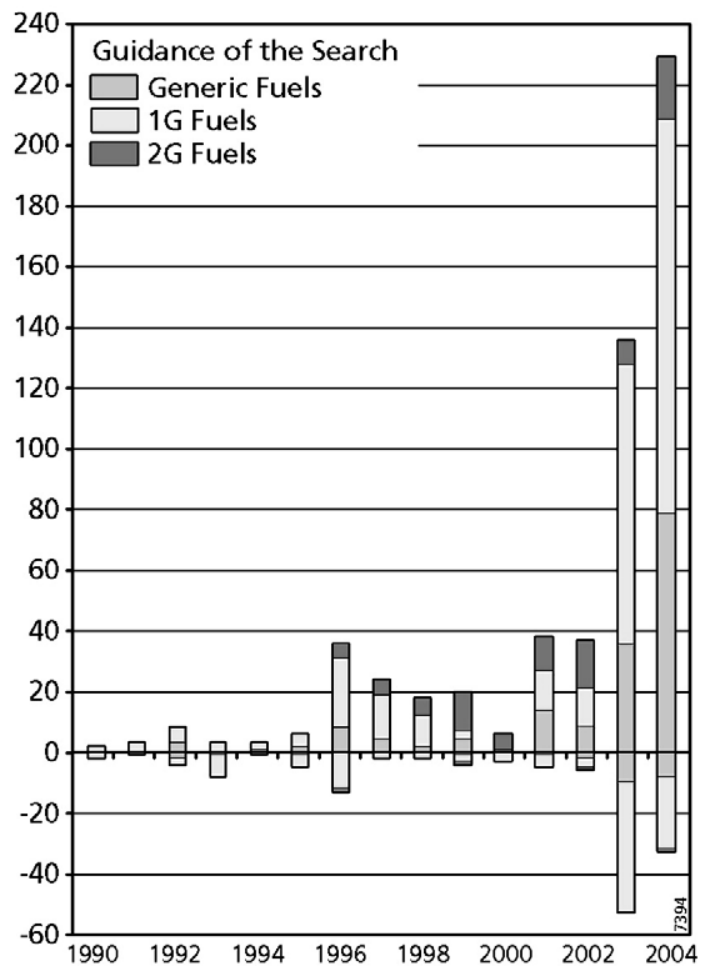

Fig. 3. Guidance of the Search [F4] [aggregated events/year].

Around the same time, in 1995, Nedalco, an alcohol producer, starts to play an influential role in pressing the national government to change the tax scheme. Nedalco's business expansion [F1] starts with a trial production of bioethanol [F2] [54]. Together with other companies, plans are made for a pilot plant [F3]; pressure is put on the government to issue a tax exemption [F7]. According to Nedalco, returns cannot cover the investments without a tax exemption [55]. Nedalco succeeds in raising attention to the possible advantages of bioethanol [F4]; see the trend in Fig. 3. Its political lobbies [F7] are complemented by positive announcements in the media [F4] and by the outcome of new assessment studies [F2], carried out under the supervision of Novem [F4], confirming the potential of its project [56] [F4]. In the summer of 1997, Nedalco succeeds in persuading [F6] the national authorities to guarantee a ten-year tax exemption [F5] for the annual production of 30 million litres of bioethanol. Furthermore, a subsidy is promised for the expansion of Nedalco's activities [F6] [57]. However, the apparent success is undone by the fact that the tax exemption turns out to be insufficient to cover the investments [55]. ${ }^{9}$ As a result, the project is discontinued [F1] and the plans remain just a promise.

Nevertheless, Nedalco's project is successful in the sense that it takes a stance against the government's resistance to (1G) biofuels. A lasting effect of Nedalco's activities is the recognition in the field of $1 \mathrm{G}$ biofuels as a viable option. Fig. 3 illustrates this trend as a rise to a high level of guidance (mainly expectations), involving all types of biofuels by 1996.

So far, not a drop of biofuel has been produced within the Netherlands, although a first attempt to supply biofuels has been made. The episode is characterised by an increasing attention on biofuels and by the first real steps being taken by national government authorities to actually support biofuels. The tax scheme remains an important barrier, still not differentiating between fossil fuels and biofuels. Also, the government mainly follows the entrepreneurs instead of taking a strategic lead. This is about to change.

In 1996 the possibility of using 'solids to liquids' technology starts receiving media coverage [F4]. Academic researchers and environmentalists have mainly been calling attention to the negative properties of $1 \mathrm{G}$ fuels [58-60], thereby discrediting the biofuels option as a whole [F4]. However, their criticism now becomes more constructive as they propose an alternative in the form of $2 \mathrm{G}$ biofuels [F4]. Previously, the $2 \mathrm{G}$ technologies group had been developed in R\&D settings [F2] but now a small company named Biofuel-a spin-off from Shell-joins forces with several industrial parties and starts working on the construction of a first pilot plant for the production of 'biocrude' [F1, F3] [61]. This R\&D project is financed by both Shell and a national subsidy programme [F6] [62].

\section{Cumulative causation}

The event sequences observed indicate the emergence of a motor. The event sequence is characterised by contributions to Entrepreneurial Activities, Knowledge Development and Knowledge Diffusion. The role of Guidance of the Search (public opinion,

\footnotetext{
${ }^{9}$ In particular, Nedalco's partners are unsatisfied with the limited volume of bioethanol qualified for a tax exemption [53].
} 
press releases, Novem) and Support from Advocacy Coalitions (especially the lobbies) has become important as well. The pivot is a recurring lobby (to the government) for resources by regional entrepreneurs [F1-F7-F6-F1]. If successful, the entrepreneurs manage to realise their projects, thereby providing a basis for positive expectations and more projects [F1-F2/F3-F4-F1]. Note that the presence of local regulations, constituting a small niche-market [F5], has been an important success factor.

Given the centrality of Entrepreneurial Activities in the interaction pattern, it makes sense to call this motor an Entrepreneurial Motor. The rise of Knowledge Development and Entrepreneurial Activities in the field of both 1G and 2G biofuels are typical for this episode; this is visible in Figs. 1 and 2. Furthermore, Figs. 3 and 4 show the shift of the Guidance of the Search and Support from Advocacy Coalitions patterns from 1995 to 1998 as a result of these developments. Fig. 5 shows how Knowledge Diffusion-in the form of workshops and meetings on biomass energy-improves during this episode.

\subsection{The separation of $1 G$ and $2 G$ biofuels (1998-2000)}

In 1998, the climate issue becomes an important background movement. A milestone is the signing of the Kyoto treaty by member states of the European Union in 1998. The European target is to realise more than $60 \%$ of the $\mathrm{CO}_{2}$ reduction through the use of biomass [63]. In the Netherlands, this target is adopted by various government programmes [64-66]. On top of this the automotive sector is increasingly considered an important target for energy policy [65,67]. ${ }^{10}$ A most significant event during this episode is the initiation by Novem of a national programme for the assessment and support of gaseous and liquid $\mathrm{CO}_{2}$-neutral energy carriers-the GAVE programme [68].

So far, the emerging BFTIS has received little government support. A troublesome factor is the biofuels controversy. GAVE manages to establish a breakthrough in the status quo, by starting up a motor that triggers the following three trend patterns.

The first trend pattern is related to Guidance of the Search. Scarcity of biomass has been increasing as a result of growing demands for electricity production [F6] [69], causing a dispute on the use of biomass streams for transport versus electricity purposes [F4] [53]. However, an influential study [F2] authorised by GAVE [70], designates that biofuel production could certainly be favourable, provided that production scales are sufficiently high [F4] [71]. Moreover, a range of alternative energy sources already exists for electricity production, whereas little has been achieved for the mobility domain [F4]. With this argument, GAVE turns to the responsible government ministries and manages to put the issue on the national policy agenda [F7] [68].

A second trend initiated by GAVE is Knowledge Development in the field of 2G biofuels. In 1999, GAVE's first move is to authorise a number of assessment studies [F2] aimed at removing the controversy around various biofuel options [F4]. A pre-study results in a shortlist of fuel chains to be analysed in more detail [72]; the results are based mainly on energy balances and cost figures [F2]. The advice is to support exclusively projects which guarantee $\mathrm{COO}_{2}$ reduction of at least $80 \%$ [F4] [68]. Subsequently, all 1G options are (de facto) excluded from further assessments. It is within this context that the term $2 \mathrm{G}$ biofuel is actually invented to distinguish the contested agricultural biofuels from technologically advanced options [68]. Figs. 2 and 3 show this trend. From 1998 to 2000 , the $2 \mathrm{G}$ biofuels attain dominance over $1 \mathrm{G}$ biofuels. The programme creates a spin-off in the form of new undertakings of Nedalco and the Biofuel Company.

The Biofuel Company starts working on a pilot plant [F1] and manages to realise a proof of principle for the HTU process, a 2G technique for the production of biodiesel, particularly suitable for (wet) waste [73]. Originally, the R\&D activities [F2] are not specifically aimed at producing automotive fuels; in fact, the possibility is barely mentioned [F4] [74]. However, from 2000 onwards and triggered by GAVE, the Biofuel Company's technological progress is increasingly considered a contribution to the substitution of petrol-based resources [F4] [74-76].

Nedalco has also shifted its attention in response to the rise of $2 \mathrm{G}$ biofuels [F1]. With the original plan discontinued (as mentioned above), Nedalco now studies the possibility of using $2 \mathrm{G}$ biofuels [F2]. A highly innovative R\&D project on the production of cellulose ethanol is initiated. Other organisations involved are Wageningen University, TNO, ${ }^{11}$ and Shell [F3]. The project is partly funded with government subsidies [F6] [55].

The third trend is GAVE's contribution to Knowledge Diffusion. As Fig. 5 shows, there are no meetings specifically on biofuel [F3] in the period 1990-1998. From 1998 onwards, general biomass energy meetings become more important, yet, they are still mostly directed at the stationary use of biomass. ${ }^{12}$ Meetings specifically on biofuel (mainly $2 \mathrm{G}$ fuels) start occurring from 1999 onwards. Fig. 3 shows the positive impact of GAVE on Guidance of the Search. From 1998 to 2000, the 2G biofuels attain dominance over $1 G$ biofuels.

\section{Cumulative causation}

The main source of dynamics in this episode is the GAVE programme. The programme serves as a catalyst, bundling and connecting activities that, until now, had been developing in relative isolation. The interaction patterns indicates that a motor has emerged which is different from the one in the previous episode. The dominant system functions are now mainly Knowledge Development, Knowledge Diffusion, Guidance of the Search and Resource Mobilisation. The Support from Advocacy Coalitions and

\footnotetext{
${ }^{10}$ Before 1998-all the way back to the post-oil crisis years-the issue of sustainable fuels for automotive purposes was largely disregarded in the Dutch political arena [53].

${ }^{11}$ TNO is the Dutch Organisation for Applied Scientific Research. The network consists of TNO and a number of companies active in chemical engineering and energy distribution.

12 Since data collection was not specifically directed at these general events, one should not conclude that there were no other general biomass meetings in this period.
} 


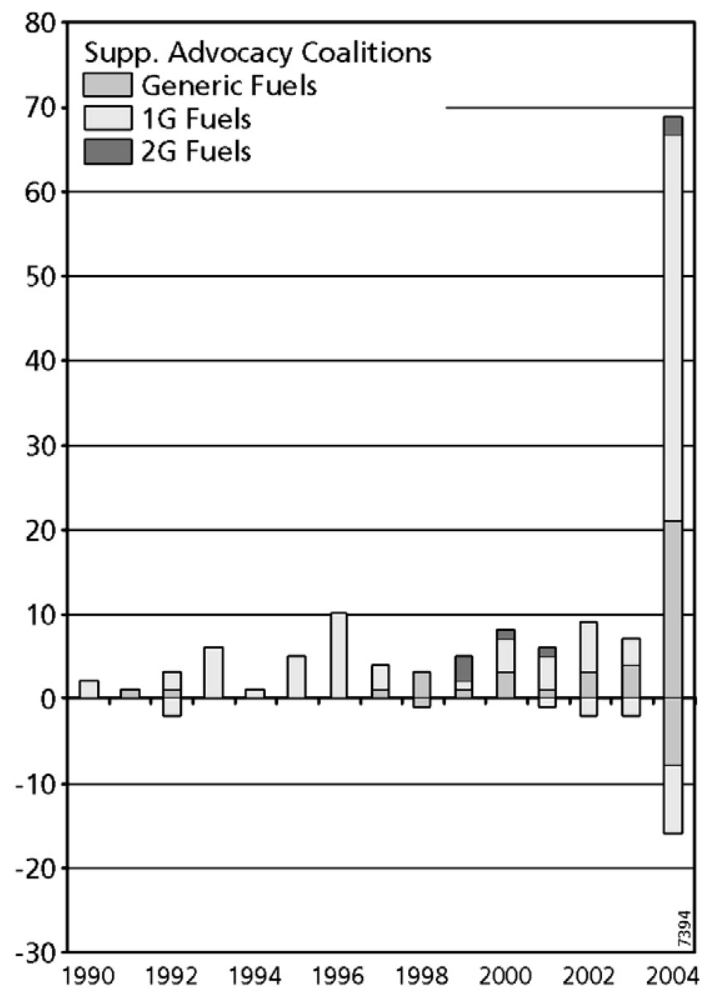

Fig. 4. Supp. Advocacy Coalitions [F7] [aggregated events/year].

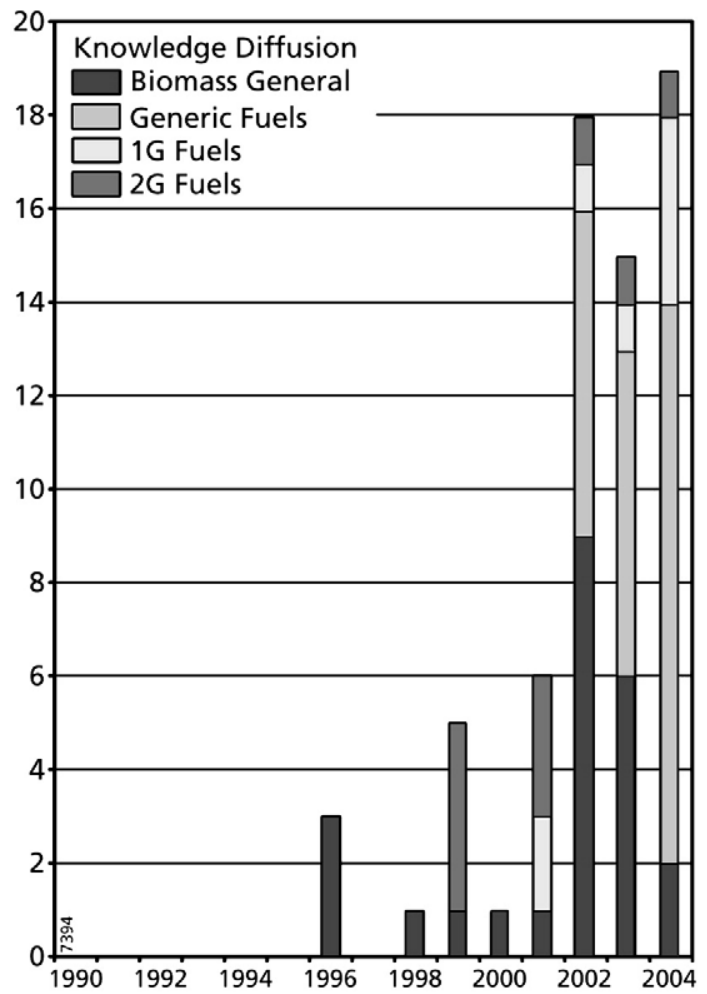

Fig. 5. Knowledge Diffusion [F3] [aggregated events/year]. 
Entrepreneurial Activities are less prominent than before. The dynamic involves positive expectations and/or research outcomes [F4] leading to the setting up of a government R\&D programme [F4] and, directly linked to it, the allocation of financial resources [F6], resulting in a boost to 'scientific' activities in the form of feasibility studies [F2], some entrepreneurial experiments [F1] and also conferences, workshops and other meetings [F3]. Given the predominance of scientists and technology developers in developing 2G biofuels, and given that projects are mainly initiated through a government programme, it makes sense to label this form of cumulative causation a Science and Technology Push (STP) Motor. Note that the dynamics that characterise this motor are driven by promises of technology developers combined with the visibility, networks, and funding delivered by the policy programme.

The promise of $2 \mathrm{G}$ technologies triggers fruitful BFTIS dynamics, yet the negative aspects of $1 \mathrm{G}$ biofuels are now further stressed [F4]. Figs. 1 and 2 show a stagnation in Entrepreneurial Activities and Knowledge Development around 1G in the late 1990s. The complete absence of a complementary policy environment for $1 \mathrm{G}$ fuels results in the exclusion of the entire technology group. Whether this will be fruitful in the long term remains to be seen. Government support now mainly focuses on R\&D and on subsidies. This can be considered risky. Apart from the 'boating niche', there are no further market dynamics.

\subsection{A tentative offer (2001-2002)}

In the new millennium, the issue of sustainable mobility is put on the political agenda. Besides the climate issue, the issue of security of oil supply is becoming more urgent, especially since 9/11. In the Netherlands, these background movements are reflected in a variety of policy measures aimed at reducing fuel consumption in the mobility domain [77]. Despite weak ministerial support, the work of GAVE continues [78]. From 2001 to 2002, GAVE installs a subsidy programme [F6] aimed at guiding entrepreneurs towards the realisation of demonstration-scale fuel chains [F4] [79-81]. The programme consists of two tenders for a total budget of approximately 2 million $€$. The first step is to stimulate the formation of coalitions [F3] and to support assessment research [F2]. The $80 \% \mathrm{CO}_{2}$-reduction criterion still holds; the emphasis is on innovative fuel production. As a result, all new projects [F1] are exclusively directed at 2G biofuel technologies.

Two entrepreneurial experiments [F1], focusing on combining biomass gasification with Fischer-Tropsch synthesis, are characteristic for this episode. If successful, they could enable the production of biodiesel from practically any biomass source [F4]. The projects are set up by two alliances [F3]; the Shell-ECN network and the TNO-Nuon network, and various other actors, such as banks, a car company, and many others [82]. The projects are successful [F4], particularly with respect to solving technological bottlenecks such as gas cleaning [F2] [83].

The final purpose of the subsidy programme was to realise a commercial demonstration. By the end of 2002, possibilities are considered [F4], as both alliances are viable candidates and GAVE has a sum of 5 million $€$ to offer [F6]. Unfortunately, both parties decide to discontinue [F1]. The main reason is that building a commercial-scale plant would cost far more than 10 million $€$, which would not be feasible without a flanking market stimulation programme, e.g. tax exemption measures [F5, F6] [68,84]. The subsidy programme stops [F6]; once again, the absence of sufficiently powerful market creation policies forms a critical barrier to the further development of the BFTIS [F5] [68]. This would require a tax exemption for biofuels or a scheme that promotes obligatory use.

Towards the end of the episode, political pressure from the EU increases [85-89]. In the Netherlands, this background movement results in a lobby from national parliament [F7] [90], pressing the national government into issuing generic tax exemptions for experiments with automotive biofuels [F5] [91-93].

\section{Cumulative causation}

The STP Motor has been running for two years now. From a technology perspective, this motor has resulted in important outcomes; see Figs. 2 and 3. Still, a crucial system function-namely Market Formation-is left unaddressed; the exclusive orientation towards $2 \mathrm{G}$ biofuels will, as we shall see, result in the neglect of potentially powerful demand-side dynamics.

\subsection{European intervention (2003-2005)}

In 2003, the EU decides on a biofuel directive forcing its members to substitute a percentage of the supplied automotive fuels by biofuels [94]. This background movement has drastic consequences as the EU is more fond of $1 \mathrm{G}$ biofuels than the Dutch government.

With GAVE's subsidy programme terminated, and with a new national task of implementing the EU directive, a reorientation of government policy is imminent [95]. Therefore GAVE is issued with a new priority task [F4]: the development of a generic market for biofuels. The $1 \mathrm{G}$ technologies are now increasingly perceived as a stepping stone towards future use of 2G fuels [68,96].

In 2003, once again, Nedalco starts influencing the field. With the directive being taken up by national policy makers [F4], the alcohol company now works on a new business plan for the large-scale production of (1G) bioethanol [F1] [55]. However, despite the policy shift [F4], concrete market stimulation measures are still not in effect [F5]. Once again, Nedalco pleads for a long-term tax exemption [F7]. Within the context of this lobby, the promise of $2 \mathrm{G}$ technologies serves as important leverage, as in the intermediate period, Nedalco's venture in R\&D on $2 \mathrm{G}$ ethanol has been extraordinary fruitful [F4] [55,68]. The national government shows interest, but does not readily respond [F4]. The project is halted [F1]; Nedalco restlessly awaits the disclosure of the future Dutch biofuels policy.

Despite the absence of a clear and supportive national programme [F4], a variety of 1G initiatives commence from 2002 onwards [F1]; see Fig. 1. One of the most influential endeavours is initiated by a company named Solar Oil Systems (SOS). This small 
business starts off adjusting conventional diesel engines to PPO fuel ${ }^{13}$ [F1], but in 2002, SOS expands its activities by preparing the construction of an oil mill. The project is supported by more than 25 partners, among them farmers, farmers' associations and local government authorities [F3] who are made shareholders [F6]. The company's downstream activities are covered by promoting biofuels to potential users [F4]. In order for the project to be financially feasible, SOS demands a tax exemption [F7] [97,98]; see Fig. 4. The government eventually agrees with the company's terms [F6].

The SOS network makes sure that multiple system functions are realised simultaneously [99], which results in a positive spinoff. In March 2005, the first Dutch oil mill is completed; the oil is delivered mainly to fleet vehicles of the provincial government. This success triggers a large number of events: from 2002 onwards, entrepreneurial projects [F1] are initiated throughout the country, most specifically in rural areas; see Fig. 1. The oil mill is often mentioned as an example [F4] [100-103].

Once again, it is the regional authorities and entrepreneurs-this time supported by a European directive-that drive the BFTIS forward. The rural developments are complemented by the initiation of the Energy Valley cluster [F3] [104]. This cluster strives for the alignment of public investments with local economic interests [F4, F7].

A remarkable trend that emerges is a counter movement formed by the oil industry, environmentalists, and academia [101,105,106]; see the negative peaks in Fig. 3 and 4. The controversy around 1G and 2G seems to increase. However, at the same time there is a stronger Guidance of the Search for 1G biofuels than ever before. Moreover, there is an increasing support, both in terms of Guidance of the Search and in terms of Support from Advocacy Coalitions, for biofuels in general. The choice for 1G or 2G biofuels was first presented as a conflict of opposites, but now it seems that the BFTIS actually supports the co-existence of the technologies.

\section{Cumulative causation}

This episode is characterised by an increasing activity level for all system functions; Figs. 1-5 all illustrate this trend. Multiple system functions are fulfilled, bottom-up, by a variety of actors that increasingly operate in networks. The perspective of a market for $1 \mathrm{G}$ biofuels-offered through the European directive-plays a crucial role in this. The renewed Guidance of the Search resulting from this initiates an interaction pattern which is, again, characterised by Entrepreneurial Activities inducing Support from Advocacy Coalitions and Resource Mobilisation. The entrepreneurs and their expectations play a pivotal role. It seems that the STP Motor of the previous episode has transformed into an Entrepreneurial Motor.

Note that these dynamics are largely the effect of the EU directive. It should be stressed that it is not until the summer of 2004 that developments take-off on the national policy level, with the release of the government's white paper on traffic emissions [F4]. This document contains a section on generic measures that need to be taken for the implementation of biofuels [107]. The 2G fuels are still considered preferable, but $1 \mathrm{G}$ fuels are explicitly considered as a stepping stone option.

\subsection{A market in distress (2006-2007)}

With oil prices rising, biofuels are becoming an ever more important subject of energy policies, not only in the EU but worldwide [37]. A drawback is that, with market diffusion of (1G) biofuels taking off globally, the resistance to biofuels is growing at the same time. The controversy becomes greater when studies show that the increased land-use for energy crops-for 1G and 2G alike-results in rising food prices and in the deforestation of vulnerable natural areas like rainforests [108].

In the Netherlands the EU directive is translated into national policies [F4]. For 2006, a generic tax exemption is issued (as a temporary measure), which is replaced, in 2007, by a scheme of obligatory blending [F4, F5]. The scheme obliges oil companies to sell biofuels as an increasing share of their fossil-derived fuel sales; from 2\% (on an energy basis) in 2007 to $5.75 \%$ in 2010 [109]. In addition, to promote R\&D on $2 \mathrm{G}$ biofuels a 60 million $€$ subsidy programme, specifically directed at $2 \mathrm{G}$ biofuels production pilots (IBB), is introduced for 2006-2014; with 12 million $€$ allocated for 2007 [F6] [110]. ${ }^{14}$

As the result of these supportive policies, the number of business start-ups increases [F1]. Biofuel plants (1G) and logistics facilities are being built in Rotterdam harbour [108]. A positive effect of the biofuels market that has been created, is that entrepreneurs no longer have to lobby for subsidies [F7]. Instead, successful businesses breed even more start-ups without the need for specific government interventions [F4] [108].

An exception is formed by entrepreneurs aiming for the further development of $2 \mathrm{G}$ technologies. The $2 \mathrm{G}$ biofuels are, as yet, not developed far enough to be commercially viable [37]. The support for R\&D, and the anticipated market, induces a number of companies, like Shell and Nedalco, to invest resources [F6] in 2G technologies R\&D [F1, F2]. Also, plans are made, most notably by Nedalco, for the construction of $2 \mathrm{G}$ pilot plants. These initiatives are, however, largely dependent on government funding, and the resources allocated are marginal [F6]. Indeed, they are comparable to what was available within GAVE and this turned out to be insufficient at the time. But now that there is a market, Nedalco continues its course of activities in much the same way as it began, by lobbying the government for a large subsidy [F7]. According to the latest information, the company was granted a subsidy for the building of a $2 \mathrm{G}$ pilot plant, but is currently (2008) uncertain whether these plan will be realised [108].

\footnotetext{
13 Pure Plant Oil (PPO) is unrefined oil extracted from rape seed. In order to use it in conventional diesel engines, a serious reconstruction is required. Regular biodiesel is usually produced from rape seed as well, but the oil is chemically refined to such an extent that it has similar characteristics as regular diesel and only marginal adjustments are necessary.

14 Note that this way the oil companies act as a gate keeper of the biofuels market; they can determine whether to supply biofuels as blends, or as pure substances.
} 
Despite the strong position in terms of Knowledge Development, entrepreneurs are generally hesitant to initiate Entrepreneurial Activities. The problem in general, for potential 2G biofuel producers, is the uncertainty of the biofuels market [F5]. After all, it remains to be seen whether $2 \mathrm{G}$ biofuels can eventually compete with $1 \mathrm{G}$ biofuels [F4]. This uncertainty is the more striking in the face of cheap imports from Brazil and Eastern Europe. In fact, even 1G biofuel producers have a hard time competing with the biofuel imports [F4, F5]. This is a reason for some entrepreneurs to call for protectionist policies in the biofuels trade, especially since some of the imported biofuels are deemed 'unsustainable' [F7] [108].

The latter point relates to a more stringent issue: a renewed rise of the biofuels controversy. With the increasing market diffusion, scientists and environmental organisations have continued to stress that biofuels are not a solution but a problem [F4, F7] [111,112]. Their distress calls are heard by politicians and the Dutch government picks up on this by falling back on the original distinction between $1 \mathrm{G}$ and $2 \mathrm{G}$ biofuels, although it is a more fine-grained distinction this time around. A system of sustainability criteria is developed that should allow policy makers to incorporate the $\mathrm{CO}_{2}$-reduction potential and land-use of particular biofuel chains [F4] [113]. The most recent development is that a debate has started, on the EU level, about the question whether the biofuels directive should be adjusted to take into account such sustainability criteria. Dutch policy makers have a large say in this discussion since they have already started to develop sustainability criteria, as a response to the early rise of a biofuels controversy in the Netherlands [F4, F7] [108].

\section{Cumulative causation}

The dynamics within this episode suggest a segregation of the development of $1 \mathrm{G}$ biofuels and $2 \mathrm{G}$ biofuels. The event sequence related to $1 \mathrm{G}$ biofuels is characterised by the creation of a market environment [F5]. This has resulted in a guaranteed demand for biofuels, leading various firms [F1], encouraged by expectations [F4], to enter the TIS and start investing in the commercial production of 1G biofuels [F1, F6]. Where successful, this leads to even higher expectations [F4] and more entries and investments of firms [F1, F6]. This form of cumulative causation may be labelled a Market Motor.

The 2G biofuel technologies are still driven by an Entrepreneurial Motor as characterised in the previous section. The further development of this motor is currently uncertain due to the rapid expansion of $1 \mathrm{G}$ biofuels.

On top of this, the biofuels controversy rages on, undermining the long-term perspective for the development of biofuel technologies, $1 \mathrm{G}$ and 2G alike [F4]. It seems that the BFTIS is on a tipping point. Either, the BFTIS actors, including the international ones, manage to establish a consensus on what biofuel options are worthy of support, or else the BFTIS will dissolve and break down as the result of ever-increasing uncertainty.

\section{Reflections}

The event history analysis has allowed us to conceptualise the development of the BFTIS in terms of system functions. Occurrences of cumulative causation have been pointed out, in the form of three motors, and particular drivers and barriers related to these motors have been revealed. In this section we will answer our research question: How did innovation system dynamics influence the formation of a Dutch biofuels innovation system from 1990-2007? This section also outlines strategic implications for policy makers and entrepreneurs.

\subsection{Lack of continuity}

As we have seen, cumulative causation mostly emerged where entrepreneurs started deliberately to shape the BFTIS. Notable examples are the boating companies and an ethanol producer, initiating an Entrepreneurial Motor, and the recent successes around $1 \mathrm{G}$ biofuels, triggering a Market Motor. Furthermore, the GAVE programme initiated virtuous dynamics in the form of an STP Motor. However, our analysis has also shown that these motors often came to a halt. As a result, there has been little continuity in the development of the BFTIS. The absence of follow-ups to Entrepreneurial Activities played a key role. This was illustrated by the isolation of the early adoption experiments with public transport, the termination of Nedalco's expansion plans, and the failure of GAVE to realise demonstration projects. Recurring barriers were the absence of Market Formation and the general lack of a consistent Guidance of the Search by the national government, both of which could have been overcome with more dedicated policies. Also entrepreneurs could have made a stronger point for the support of virtuous dynamics, as will be discussed below.

In general, our case shows that the fulfilment of various system functions is important and that during the build-up of system function fulfilment, various forms of cumulative causation-motors of innovation-play a role. Ideally, these motors coexist, but more realistically, they will gradually emerge and follow up on each other to provide 'step by step' increases in functionality of the TIS. For instance, a motor exclusively driven by subsidised R\&D may pave the way for a market-based motor phasing in later. The challenge for policy makers and entrepreneurs is to be aware of such possibilities, to facilitate the necessary underlying interactions, and to be flexible, yet enduring, in response to unexpected shifts.

\subsection{The linear model of innovation}

The strength of a systematic and consistent policy approach is shown by the main success of the Dutch biofuels policy: its impulse to R\&D developments around $2 \mathrm{G}$ biofuels via the GAVE programme. The resulting technical successes were internationally appreciated. However, as soon as the national government decided that biofuels were to be supported, its strategy was to initiate exclusively Knowledge Development among incumbent industry networks. The orientation was on lab-scale Knowledge 
Development whereas Market Formation activities were absent. The failure of GAVE to start demonstration projects can be ascribed to the absence of such complementary system functions, mostly Guidance of the Search and Market Formation. As a result, the 2G projects were a technical success, but turned out to be economically infeasible.

The general lesson to draw from this is that the linear model of innovation is still operational today. If the sole purpose of a governments is to boost R\&D, the other activities of the system are neglected, meaning that potentially powerful feedbacks remain absent.

\subsection{A controversy}

The absence of a broader scheme of national support can be related to the controversy on whether $1 \mathrm{G}$ biofuels have the potential to contribute significantly to a sustainable mobility domain. Environmental organisations, academic scientists, and oil companies have pressed officials on the national level to refrain from support, whereas entrepreneurs and farmers have stressed the opportunities for economic growth and environmental gain. As a result, the great variety within the BFTIS has become the driver of a conflict that continues today. This conflict is mirrored in the realisation of various system functions, mainly in Guidance of the Search and Support from Advocacy Coalitions. The conflict is largely caused by the fact that the national government has not taken a clear stance. On the one hand, project-specific tax exemptions were issued, thereby fostering the $1 \mathrm{G}$ biofuels, while, on the other hand, the government increasingly adhered to arguments of the counter lobby, promoting $2 \mathrm{G}$ fuels. The other side of the story is that entrepreneurs and scientists did not adhere to a joint cause, rendering a conflict almost impossible to avoid.

The result was that when the EU directive was issued in 2003, the TIS was hardly developed enough to diffuse biofuels into the market. Perhaps excluding alternatives from support is sometimes justified. In the case of emerging technologies, however, it can be argued that such choices are unwise as technological performances are as yet uncertain. Moreover, the emergence of motors depends on the preservation of variety within the TIS. The implication for entrepreneurs and other private actors is to bury the hatchet with respect to their mutual disagreements and to join forces. Only by 'running in packs' can they increase their chances of establishing a foothold within the incumbent mobility domain; cf. Van de Ven [34]. A joint effort would also contribute to the construction of a shared vision. This would serve as a beacon for policymakers in search for a consistent policy framework. The challenge for policy makers is then to refrain from selecting technologies altogether, and, instead, to build and facilitate an environment consisting of actors and institutions aiming for inclusion.

\subsection{Levels of government authority}

The development (and policy) of biofuels has largely been the result of European pressure. The Dutch government was-for numerous reasons-not particularly inclined to respond to European signals. A striking outcome of our analysis is that it was mainly small entrepreneurs, collaborating with farmers' associations, providers of public transport, and provincial fleet owners that picked up these incentives. Also the (regulatory) Guidance of the Search, Resource Mobilisation, Market Formation, and much of the Knowledge Development relevant for the entrepreneurs was provided by public authorities on the level of regions and provinces. Of the three motors identified, national policy only played an initiating role in one of them-the STP Motor. The other motors were generally hampered rather than supported by the national government.

This observation can be related to the more general discussion on globalisation, and the simultaneous regionalisation, of knowledge-based economies. Despite the importance of a nation as a politico-economic entity, one cannot deny the increasing importance of global and regional innovation processes. A theoretical implication is that a TIS analysis may benefit from a more systematic analysis of the European policy level; this way factors that are now considered exogenous may appear as part of the endogenous dynamics. A practical implication is that the policy maker at the national level does not necessarily have to be a prime mover. In fact authorities and entrepreneurs at the local level could well take the initiative. A case in point is the fact that the more influential motors (the Entrepreneurial Motor and the Market Motor) both started off as 'Europe-driven' regional developments. National government could have backed up these developments by targeting the system functions that were yet poorly developed.

\subsection{Summary}

In short, the formation of a TIS requires that multiple system functions are increasingly fulfilled by a broad group of actors, consisting of governments and entrepreneurs alike. Within the Dutch BFTIS the conditions have not been very supportive for this to happen. With conflicting views by entrepreneurs, environmentalists and scientists, and with the national government hampering most system functions, the emerging motors have largely failed to develop. Only recently has the European biofuels directive resulted in the creation of a market for biofuels. This seems to have triggered virtuous dynamics within the BFTIS, both among entrepreneurs and policy makers, although the biofuels controversy still rages on and the future of the BFTIS seems more uncertain than ever.

\section{Concluding remarks}

We started this paper by expressing the need for increased insight into the formative stage of innovation system development, particularly in order to be able to support sustainable energy innovations. We adopted the TIS framework and argued for a focus on system functions. By analysing and evaluating the development of biofuels in the Netherlands, we illustrated how the build-up of 
system functions can be conceptualised and measured over time. Our study empirically confirmed the importance of dynamics, and offered insights into the influence of various motors of innovation that contributed to the build-up of a TIS.

Our case study revealed three motors that supported biofuels development in the Netherlands; an Entrepreneurial Motor, a Science and Technology Push (STP) Motor and a (promising) Market Motor. The STP Motor involved research and development guided by a government programme. The Entrepreneurial Motor was initiated by entrepreneurs pushing government to support them. The promising Market Motor was driven by positive expectations and policies directed at the formation of a mass market.

What does this add to the existing innovation systems literature? First of all, our approach allows for a fruitful combination of quantitative and qualitative analysis, that is fit for recognising and interpreting historical patterns. In our case study we systematically pointed out how system functions developed and interacted. The motors and their effects, spanning a long period of time and covering a broad variety of activities, could not have been identified by using a more traditional approach, such as a patent analysis or a formal network study. Nor could such dynamics have been found by describing and comparing institutional setups for different innovation systems.

Second, our approach offers advantages with respect to the integration of empirical and conceptual work. With event history analysis, case studies can be conducted in a systematic way, with the list of system functions serving as a powerful heuristic framework. By focussing on events, clustering them in event types, and then (indirectly) attributing them to system functions, a 'self-fulfilling prophecy' bias is prevented. This is important as the system functions, as concepts, are still in the process of being validated. If more case studies are carried out in this way, then the dynamics of different TISs can be compared, leading to a more general insight into what system functions matter, and into the types of motors that (may) occur. This way, eventually, this empirical approach has the potential to make a strong contribution to a better theoretical understanding of innovation system dynamics.

Our approach provides a new perspective on energy and innovation policies. Instead of targeting mainly the supply-side (R\&D programmes) or the demand-side (market creation policies) of the innovation chain, it stresses the systemic nature of technological change. This means that policy instruments should contribute to the formation of new technological innovation systems, thereby increasing the success chances of new technologies. The set of system functions offers a heuristic model that indicates the most crucial policy targets. If a particular system function is lacking, attention should be paid to it. In more advanced policy designs, the presence of motors should be monitored, and policy may then be directed at supporting these forms of cumulative causation.

There are also implications for entrepreneurs active in an emerging technological field. Their chances of survival will improve when the innovation system develops further. Therefore they should be aware of innovation system dynamics and their pivotal role in contributing to motors. By running in packs, and organising themselves into alliances, they are likely to be more influential, and more successful in innovating.

\section{Acknowledgements}

The authors would like to thank Professor Staffan Jacobsson for extensive feedback on an earlier version of this article. Finally, we would like to thank the 'Knowledge Network on System Innovations and Transitions (KSI)' and the 'Netherlands Organization for Scientific Research (NWO)' for their financial support.

\section{References}

[1] E.S. Andersen, B. Lundvall, H. Sorrn-Friese, Editorial, Res. Policy 31 (2) (2002) 185-190.

[2] B. Carlsson, S. Jacobsson, M. Holmén, A. Rickne, Innovation systems: analytical and methodological issues, Res. Policy 31 (2) (2002) $233-245$.

[3] B. Carlsson, R. Stankiewicz, On the nature, function, and composition of technological systems, J. Evol. Econ. 1 (2) (1991) $93-118$.

[4] B.-Å. Lundvall, National Systems of Innovation - Toward a theory of Innovation and Interactive Learning, Pinter Publishers, London, 1992.

[5] M.P. Hekkert, R.A.A. Suurs, S.O. Negro, S. Kuhlmann, R.E.H.M. Smits, Functions of Innovation systems: a new approach for analysing technological change, Technol. Forecast. Soc. Change 74 (2007) 413-432.

[6] S. Jacobsson, A. Bergek, Transforming the energy sector: the evolution of technological systems in renewable energy technology, Ind. Corp. Change 13 (5) (2004) 815.

[7] B.-Å. Lundvall, Post Script: Innovation System Research: Where It Came from and where It Might Go, in: B.-Å. Lundvall (Ed.), National Systems of Innovation: Toward a Theory of Innovation and Interactive Learning, Aalborg Department of Business Studies, Aalborg University, 2007, Electronic Version.

[8] D. Collingridge, The Social Control of Technology, Pinter Publishers, London, 1980.

[9] IEA, Renewable Energy, Market and Policy Trends in IEA Countries, 2004, p. 43.

[10] G.C. Unruh, Understanding carbon lock-in, Energy Policy 28 (12) (2000) 817.

[11] V. Coates, M. Farooque, R. Klavans, K. Lapid, H.A. Linstone, C. Pistorius, A.L. Porter, On the future of technological forecasting, Technol. Forecast. Soc. Change 67 (2001) 1-17.

[12] T.P. Hughes, Networks of Power: Electrification in Western Society 1880-1930, John Hopkins University Press, Baltimore, MD, USA, 1983.

[13] A. Bergek, Shaping and Exploiting Technological Opportunities: The Case of Renewable Energy Technology in Sweden (Thesis), 2002.

[14] C. Edquist, Systems of innovation: perspectives and challenges, in: J. Fagerberg, D.C. Mowery, R.R. Nelson (Eds.), The Oxford Handbook of Innovation, Oxford University Press, Oxford, 2004.

[15] X. Liu, S. White, Comparing innovation systems: a framework and application to China's transitional context, Res. Policy 30 (2001) $1091-1114$.

[16] A. Rickne, New Technology-Based Firms and Industrial Dynamics (Thesis), 2000.

[17] M.S. Poole, A.H. van de Ven, K. Dooley, M.E. Holmes, Organizational Change and Innovation Processes, Theories and Methods for Research, 2000.

[18] K. Blok, Renewable energy policies in the European Union (guest editorial), Energy Policy 34 (2005) 251-255.

[19] B.-Å. Lundvall, A. Johnson, E.S. Andersen, B. Dalum, National systems of production, innovation and competence building, Res. Policy 31 (2002) $213-231$.

[20] C. Freeman, The 'National System of Innovation' in historical perspective, Camb. J. Econ. 19 (1) (1995) 5-24.

[21] B.-A.. Lundvall, Innovation as an interactive process: from user-producer interaction to the national system of innovation, in: G. Dosi, et al., (Eds.), Technical Change and Economic Theory, Pinter, London, 1988.

[22] S. Jacobsson, A. Johnson, The diffusion of renewable energy technology: an analytical framework and key issues for research, Energy Policy 28 (9) (2000) 625-640. 
[23] S.O. Negro, M.P. Hekkert, R.E. Smits, Explaining the failure of the Dutch innovation system for biomass digestion-a functional analysis, Energy Policy 35 (2007) $925-938$.

[24] S.O. Negro, R.A.A. Suurs, M.P. Hekkert, The bumpy road of biomass gasification in the Netherlands: explaining the rise and fall of an emerging innovation system, Technol. Forecast. Soc. Change 75 (1) (2008) 57-77.

[25] S.O. Negro, Dynamics of Technological Innovation Systems - The case of biomass energy (Thesis), 2007.

[26] S. Borrás, System of Innovation Theory and the EU (Draft), 2004.

[27] B. Carlsson, S. Jacobsson, Dynamics of innovation systems. Policy-making in a complex and non-deterministic world, Paper presented at the 'International Workshop on Functions of Innovation Systems' at the University of Utrecht, 2004, June 23-24th.

[28] A. Johnson, Functions in Innovation System Approaches. Mimeo, Department of Industrial Dynamics, Chalmers University of Technology., 2001.

[29] A. Bergek, S. Jacobsson, B. Carlsson, S. Lindmark, A. Rickne, Analyzing the functional dynamics of technological innovation systems: a scheme of analysis, Res. Policy 37 (2008) 407-429.

[30] R.A.A. Suurs, Motors of sustainable innovation. Towards a theory on the dynamics of technological innovation systems (Thesis), 2009.

[31] F. Alkemade, C. Kleinschmidt, M.P. Hekkert, Analysing emerging innovation systems: a functions approach to foresight, Int. J. Foresight Innov. Policy 3 (2) (2007).

[32] L. Kamp, Learning in wind turbine development - a comparison between The Netherlands and Denmark. Thesis, Utrecht University, 2002.

[33] S. Jacobsson, B.A. Sandén, L. Bångens, Transforming the energy system - the evolution of the German technological system for solar cells, Technol. Anal. Strateg. Manag. 16 (2004) 3-30.

[34] A.H. Van de Ven, The development of an infrastructure for entrepreneurship, J. Bus. Venturing 8 (1993) 211-230.

[35] A.H. Van de Ven, D.E. Polley, R. Garud, S. Venkataraman, The Innovation Journey, Oxford University Press, 1999.

[36] P. Abell, The Theory and Method of Comparative Narratives, Clarendon Press, Oxford, 1987.

[37] C. Schubert, Can biofuels finally take center stage? Nat. Biotechnol. 24 (7) (2006) 777-784.

[38] NRC Handelsblad. January 20th 1991: Kansen voor kleine boeren in nieuwe landbouwpolitiek EG.

[39] NRC Handelsblad. February 19th 1992: EG wil produktie van biobrandstof stimuleren door accijnsverlaging.

[40] EU, Council Regulation No. 1765/92 - of 30 June 1992 - establishing a support system for producers of certain arable crops, 1992.

[41] Trouw. February 20th 1992: EG wil accijns op biobrandstoffen fors verlagen.

[42] Algemeen Dagblad. June 3th 1992: Proef met bus op bio-alcohol in Groningen.

[43] De Gelderlander. May 30th 1995: Ontvlambare ‘suikerbus' mag blijven rijden.

[44] Algemeen Dagblad. May 7th 1992: Milieu gebaat bij bio-ethanol als motorbrandstof.

[45] NRC Handelsblad. August 8th 1992: Vierde gewas' moet eenzijdige akkerbouw redden.

[46] Algemeen Nederlands Persbureau. May 27th 1993: Bukman sceptisch over kansen bio-brandstof

[47] Algemeen Nederlands Persbureau. April 1993: SER voor proefprojecten met biobrandstof.

[48] Trouw. May 28th 1993: Bukman gelooft niet in benzine uit koolzaad.

[49] Algemeen Dagblad. May 29th 1992: Milieu-effect van biodiesel is positief.

[50] Duurzame Energie. June 1995: Energiewinning uit biomassa begint inhaalrace.

[51] Duurzame Energie. February 1996: Samenvatting EWAB '96.

[52] Het Financieele Dagblad. March 8th 1995: Biodiesel tijdelijk vrij van accijns.

[53] MinVROM, Personal communication with a senior policy maker, 2006.

[54] Het Financieele Dagblad. May 22nd 1996: Suikerunie zet conserven in de etalage.

[55] Nedalco, Personal communication with the biofuels manager, 2005.

[56] Energie \& MilieuSpectrum. September 1996: Alcoholproducent overweegt bio-ethanol te gaan produceren.

[57] De Stem. February 20th 1998: Nedalco maakt alcohol uit melasse.

[58] Duurzame Energie. June 1996: Stroomopwekking met biomassa levert beste rendement op.

[59] Duurzame Energie. June 1996: Biodiesel: 'Commercieel succes?'

[60] Duurzame Energie. August 1996: Introductie biomassa komt van de grond.

[61] Energie \& MilieuSpectrum. January 1997: De productie van ruwe olie uit biomassa; Haalbaarheidsstudie schetst optimistisch maar haalbaar beeld.

[62] Biofuel, Personal communication with company manager 2005.

[63] EU, Energy for the future: renewable sources of energy. (com(97)599 final, 1997.

[64] Duurzame Energie. August 1998: Bamboe het nieuwe energiegewas?

[65] Energie \& MilieuSpectrum. October 1998: Nog steeds subsidie voor zuinige voertuigen.

[66] Energie \& MilieuSpectrum. November 1998: Verkeer biedt goedkoopste CO2-reductie; Optiedocument zet potentiële maatregelen op een rij.

[67] Energie \& MilieuSpectrum. August 1998: Klimaatbeleid tot 2020 kan niet zonder CO2-opslag en biomassa; Besparing en efficiëntieverbetering bieden onvoldoende soelaas.

[68] GAVE, Personal communication with the programme manager, 2005.

[69] Stromen. May 25th 1999: De Europese markt voor biomassa is zeer divers.

[70] KEMA, Optimale inzet van biomassa voor energieopwekking (GAVE report no. 2), 2000.

[71] Stromen. March 16th 2001: Concurrentie tussen biostroom en biobrandstof.

[72] GAVE, Een energiek klimaat voor neutrale dragers. Eindadvies van de inventarisatie van het GAVE-programma., 1999.

[73] Duurzame Energie. December 1999: HTU-Installatie: olie uit biomassa mogelijk.

[74] NRC Handelsblad. October 1999: 'Groene' olie kan aardolie vervangen.

[75] Energie \& MilieuSpectrum. April 2000: Vervanging voor benzine, diesel en aardgas.

[76] Novem, Projectenoverzicht on www.novem.nl. HTU-proces voor de conversie van biomassa naar vloeibare energiedrager, 2000.

[77] MinVROM, Nationaal Milieubeleidsplan 4 (Environmental Policy White Paper), 2001.

[78] Stromen. February 16th 2001: Biobrandstof uit hout is beter.

[79] GAVE, Nieuwe rapporten op de GAVE website. NOVEM GAVe-mail 2003 nr.11., 2003.

[80] Stromen. September 14th 2001: Subsidieprogramma GAVE 2001 geopend.

[81] Stromen. March 22nd 2002: GAVE 2002.

[82] GAVE, Overzicht projectenprogramma GAVE-2001. NOVEM GAVe-mail 2002 nr.1, 2002.

[83] H. Boerrigter, H.D. Uil, H.-P. Calis, Green Diesel from Biomass via Fischer-Tropsch synthesis: New Insights in Gas Cleaning and Process Design, 2002.

[84] GAVE, Mogelijkheden productie Fischer Tropsch brandstof via biomassa vergassing nader onderzocht. NOVEM GAVe-mail 2002 nr.9, 2002.

[85] Algemeen Nederlands Persbureau. November 7th 2001: Europese Commissie promoot biobrandstoffen.

[86] EU, European transport policy for 2010: time to decide., 2001.

[87] Stromen. July 13th 2001: Biobrandstof.

[88] Stromen. November 23th 2001: Biobrandstoffen.

[89] Trouw. June 16th 2001: Bio-brandstof in benzine.

[90] Algemeen Nederlands Persbureau. May 22nd 2001: Vervoerders gaan van start met accijnsvrije diesel.

[91] Het Financieele Dagblad. October 2nd 2001: Bos steunt proef biobrandstof: vrijstelling accijns.

[92] Stromen. June 9th 2001: Accijnsvrije diesel.

[93] Stromen. October 12th 2001: Proef biobrandstof.

[94] EU, Directive 2003/30/EC of the European parliament and of the council of 8 may 2003 on the promotion of the use of biofuels or other renewable fuels for transport, 2003. 
[95] Stromen. February 28th 2003: Alleen door verplichtstelling kunnen biobrandstoffen doorbreken in Nederland.

[96] MinEZ, Personal communication with a senior policy maker, 2007.

[97] Bizz. November 15th 2002: De Oliemolen (2).

[98] Bizz. October 18th 2002: Olie in de autotank.

[99] Solar Oil Systems, Personal communication with the manager, 2005.

[100] Dagblad van het Noorden. August 11th 2004: Accijnsvrij.

[101] Dagblad van het Noorden. January 20th 2005: Koolzaad-biodiesel: strohalmenpolitiek.

[102] Leeuwarder Courant. October 19th 2004: Koolzaadauto's ruiken naar frituurvet.

[103] Provinciale Zeeuwse Courant. August 12th 2004: Biodieselfabriek in Zeeuws-Vlaanderen kan in 2005 draaien.

[104] EV, Website: www.energyvalley.nl, 2006.

[105] Algemeen Nederlands Persbureau. September 13th 2003: Van Geel: Alcohol in benzine goed voor milieu.

[106] Duurzame Energie. October 2003: Koolzaadteelt op langere termijn onrendabel.

[107] MinVROM, Beleidsnota Verkeersemissies (Traffic Emissions Policy White Paper), 2004.

[108] SenterNovem, Personal communication during a dialogue with five senior policy consultants, 2008.

[109] DG, Staatsblad nr 542. Besluit Biobrandstoffen Wegverkeer 2007. Besluit van 20 oktober 2006, houdende regels met betrekking tot het gebruik van biobrandstoffen in het wegverkeer, 2006.

[110] MinTr, Besluit houdende vaststelling van het Subsidieprogramma CO2-reductie Innovatieve Biobrandstoffen voor transport, als bedoeld in artikel 2, eerste lid, van de Subsidieregeling CO2-reductie verkeer en vervoer. (Hoofddirectie Juridische Zaken Nr. HDJZ/S\&W/2006-1814), 2006.

[111] J. Fargione, J. Hill, D. Tilman, S. Polasky, and P. Hawthorne, Land Clearing and the Biofuel Carbon Debt, Science 10 (2008).

[112] T. Searchinger, R. Heimlich, R.A. Houghton, F. Dong, A. Elobeid, J. Fabiosa, S. Tokgoz, D. Hayes, T.-H. Yu, Use of U.S. croplands for biofuels increases greenhouse gases through emissions from land use change, Sci. Express 319 (5867) (2008) 1238-1240.

[113] ET, Toetsingskader voor duurzame biomassa. Eindrapport van de projectgroep 'Duurzame productie van biomassa'. Advies van de projectgroep in opdracht van het interdepartementale Programma Directie Energietransitie, 2007.

Roald A. A. Suurs is assistant professor at the Innovation Studies Group, department of Innovation and Environmental Sciences at Utrecht University. His key topics of interest are technological transitions, innovation systems analysis and sustainable development in the energy domain.

Marko P. Hekkert is full professor at the Innovation Studies Group, department of Innovation and Environmental Sciences at Utrecht University. He coordinates research and education in the field of sustainable technology development and innovation system dynamics.

The Department of Innovation and Environmental Sciences is part of the Copernicus Institute for Sustainable Development and Innovation. 